\title{
OSIĄGANIE KONWERGENCJI NADZORCZEJ MIKROOSTROŻNOŚCIOWEJ I MAKROOSTROŻNOŚCIOWEJ W PRAWIE RYNKU FINANSOWEGO UNII EUROPEJSKIEJ*
}

\section{UWAGI WSTĘPNE}

Integracja nadzorcza $\mathrm{w}$ prawie rynku finansowego w okresie pokryzysowym jest szczególnie wdzięcznym obszarem badawczym, zarówno z punktu widzenia rozwijającej się teorii prawa rynku finansowego, jak i dla praktyki rynkowej ${ }^{1}$. Powołanie Europejskiego Systemu Nadzoru Finansowego (ESNF) oraz Europejskiej Unii Bankowej (EUB), umiejscowienie rozważań o unijnym nadzorze nad rynkiem finansowym i regulacji prawnych w Europejskiej Sieci Stabilności Finansowej (ESSF) jest nie tylko pożądane, ale wyznacza sieciowy i wielopłaszczyznowy charakter prawny współczesnego nadzoru mikroostrożnościowego, jak i makroostrożnościowego, zarówno na poziomie UE z Europejską Radą ds. Ryzyka Systemowego (ERRS) w filarze makroostrożnościowym² i Europejskimi Organami Nadzoru Finansowego w filarze mikroostrożnościowym $^{3}$, jak i z makroostrożnościowymi oraz mikroostrożnościowymi nadzorcami krajowymi.

* Wybrane tezy artykułu były prezentowane w ramach wystapienia na międzynarodowej konferencji naukowej Jean Monnet Seminar 2018 „Konwergencja administracji publicznej w państwach członkowskich Unii Europejskiej”, Kraków, 17-18 października 2018 r.

${ }^{1}$ E. Fojcik-Mastalska, Prawo rynku finansowego w systemie prawa, w: A. Jurkowska-Zeidler, M. Olszak (red.), Prawo rynku finansowego. Doktryna. Instytucje. Praktyka, Warszawa 2016, s. 19-26; C. Kosikowski, Nowe prawo rynku finansowego Unii Europejskiej, w: A. Jurkowska-Zeidler, M. Olszak (red.), op. cit., s. 27-38; A. Jurkowska-Zeidler, Prawo Unii Bankowej, w: eadem, M. Olszak (red.), op. cit., s. 74-93.

${ }^{2}$ Rozporządzenie Parlamentu Europejskiego i Rady (UE) nr 1092/2010 z 24 listopada 2010 r. w sprawie unijnego nadzoru makroostrożnościowego nad systemem finansowym i ustanowienia Europejskiej Rady ds. Ryzyka Systemowego, Dz. Urz. UE L 331 z 15 grudnia 2010 r., s. 1 (dalej jako: rozporządzenie o ERRS).

${ }^{3}$ Unijni nadzorcy nad rynkiem finansowym UE (ang. European Supervisory Authorities, ESA) to: 1) EBA: European Banking Authority - rozporządzenie Parlamentu Europejskiego i Rady (UE) nr 1093/2010 z 24 listopada 2010 r. w sprawie ustanowienia Europejskiego Urzędu Nadzoru (Europejskiego Urzędu Nadzoru Bankowego), zmiany decyzji nr 716/2009/WE oraz uchylenia decyzji Komisji 2009/78/WE, Dz. Urz. UE L 331 z 15 grudnia 2010 r., s. 12 ze zm. (dalej jako: rozporządzenie o EBA); 2) ESMA (European Securities Market Authority) - rozporządzenie Parlamentu Europejskiego i Rady (UE) nr 1095/2010 z 24 listopada 2010 r. w sprawie ustanowienia Europejskiego Urzędu Nadzoru (Europejskiego Urzędu Nadzoru Giełd i Papierów Warto- 
Integracja na rynku finansowym, zapewnianie stabilności finansowej odbywa się w ten sposób, że na poziomie UE wyznaczane są określone wzorce normatywne postępowania nadzorców względem instytucji finansowych, instytucji finansowych względem nadzorców krajowych i unijnych oraz względem konsumentów rynku finansowego. Integracja tego rynku, z uwagi na zmianę paradygmatu regulacyjnego na nadzorczy, powoduje, że również integracja na tym rynku ma zdecydowany charakter nadzorczy.

Celem niniejszego artykułu jest dlatego zagadnienie konwergencji nadzorczej na rynku finansowym zarówno w aspekcie mikro-, jak i makroostrożnościowym, systemowym i umiejscowienie tego procesu w sieciowym układzie zależności po zmianach prawnych wywołanych wprowadzeniem ESNF i EUB ${ }^{4}$. W szczególności analizie poddano wybrane instrumenty i mechanizmy, zarówno unijne, jak i krajowe (polskie), służące osiaganiu tej zbieżności nadzorczej, jako warunku sine qua non urzeczywistniania celu stabilności finansowej, a zarazem ilustrujące konwergencję administracji finansowej na rynku finansowym UE oraz skutki prawne i rezultaty tej konwergencji $\mathrm{w}$ wymiarze instytucjonalnym, proceduralnym, materialnoprawnym i sieciowym. Osiagnięcie stabilności finansowej - normatywnego celu regulacji rynkowych, jest bowiem bardziej realne w sytuacji stworzenia takich instrumentów prawnych, które pozwola od strony instytucjonalnej i funkcjonalnej w realizacji spójnej polityki nadzorczej na rynku wewnętrznym, co jest szczególnie istotne w ujęciu transgranicznej działalności podmiotów i z uwagi na potrzebę minimalizacji efektu ,zarażania”. Pewna doza opcyjności i swobody interpretacyjnej dla krajowych nadzorców jest jednak również niezbędna na krajowym rynku finansowym. Celem przedstawianego artykułu jest też ocena obowiąujących instrumentów i mechanizmów tej konwergencji oraz wskazanie na wady i zalety przyjętych na poziomie UE i krajowym rozwiazań prawnych w tym zakresie, charakteryzujących bezpieczeństwo prawne i obrotu prawnego na rynku finansowym.

ściowych), zmiany decyzji nr 716/2009/WE oraz uchylenia decyzji Komisji 2009/77/WE, Dz. Urz. UE L 331 z 15 grudnia 2010 r., s. 84 ze zm. (dalej jako: rozporządzenie o ESMA) oraz 3) EIOPA (European Insurance and Ocupational Pension Fonds Authority) - rozporządzenie Parlamentu Europejskiego i Rady (UE) nr 1094/2010 z 24 listopada 2010 r. w sprawie ustanowienia Europejskiego Urzędu Nadzoru (Europejskiego Urzędu Nadzoru Ubezpieczeń i Pracowniczych Programów Emerytalnych), zmiany decyzji nr 716/2009/WE oraz uchylenia decyzji Komisji 2009/79/WE, Dz. Urz. UE L 331 z 15 grudnia 2010 r., s. 48 ze zm. (dalej jako: rozporządzenie o EIOPA).

${ }^{4}$ Zastosowanie do ESNF i również EUB dobrodziejstw koncepcji sieci administracyjnych umożliwia bardziej kompleksowe tłumaczenie zmian w architekturze finansowej UE właśnie za pomocą analizy procesu konwergencji nadzorczej, odnoszącej się do uwarunkowań sieciowych, czyli relacji poziomych i pionowych między podmiotami szczebla unijnego i krajowego dla pogłębiania procesów integracyjnych, w tym przypadku na rynku finansowym UE, zarówno w aspekcie instytucjonalnym, treściowym, proceduralnym, jak i funkcjonalnym. O koncepcji sieci administracyjnych zob. zwłaszcza J. Supernat, Koncepcja sieci organów administracji publicznej, w: J. Zimmermann (red.), Koncepcja systemu prawa administracyjnego, Warszawa 2007, s. 207; R. Grzeszczak, Wtadza wykonawcza w systemie Unii Europejskiej, Warszawa 2011, s. 100 i n. O finansowej sieci stabilnościowej w polskiej literaturze przedmiotu kompleksowo w odniesieniu do rynku finansowego UE: A. Jurkowska-Zeidler, Bezpieczeństwo finansowe w świetle prawa Unii Europejskiej, Warszawa 2008, passim. 
Przyjęta tezą opracowania jest twierdzenie o możliwości wyodrębnienia trzech, równoważnych, uzupełniających się regulacyjnych sposobów osiagania konwergencji nadzorczej na rynku finansowym, które w niniejszej publikacji będą podlegały analizie, a które pomagają i urzeczywistniają założenie o uwzględniającym stabilność finansową zarządzaniu rynkiem finansowym UE. Istotne jest przy tym, że np. zasadniczo niewiążący charakter prawny instrumentów konwergencji nadzorczej makroostrożnościowej nie powoduje, że nadzór makroostrożnościowy można uznać za mniej efektywny, tylko że istota tego nadzoru wyraża się najpełniej właśnie w konwergencji instytucjonalnej i sieciowej. Konwergencja nadzorcza na rynku finansowym UE osiagana jest nie tylko przez dążenie do zbieżności materialnoprawnej i ujednolicania przepisów prawnych, konstruowanych coraz częściej w bezpośrednio skutecznych i stosowalnych rozporządzeniach unijnych, ale również osiagana jest w drodze tworzenia procedur i instytucji, które realizować mają na rynku funkcje ochronne i zabezpieczające realizację przepisów unijnych. Dlatego w niniejszym opracowaniu formułowana jest teza o istnieniu konwergencji nadzorczej na rynku finansowym nie tylko treściowej, lecz także proceduralnej i instytucjonalnej oraz zwłaszcza - kluczowej z punktu widzenia prawidłowego administrowania rynkiem finansowym UE - sieciowej. W artykule przedstawiono także metody i sposoby osiagania tej konwergencji z uwzględnieniem sieciowej, wielopłaszczyznowej konstrukcji prawnej współczesnej architektury na rynku finansowym UE. W opracowaniu zastosowano metodę dogmatycznoprawną.

\section{KONWERGENCJA NADZORCZA JAKO POJĘCIE PRAWNE NA RYNKU FINANSOWYM}

Konwergencja to inaczej zbieżność, a w analizach przedstawianego opracowania chodzi o zbieżność prawna, dokonywaną za pomocą różnych mechanizmów i instrumentów wyrażonych w przepisach prawa rynku finansowego na poziomie UE i krajowym. Na rynku finansowym konwergencja może przybierać postać pełnej unifikacji norm nadzorczych. Z taką sytuacją mamy do czynienia $\mathrm{w}$ odniesieniu $\mathrm{np}$. do norm ostrożnościowych, które regulowane są w rozporządzeniu $\mathrm{CRR}^{5}$. Konwergencja może jednak również polegać na harmonizacji prawnej zagadnień nadzorczych, rozumianej jako wyznaczanie pewnego normatywnego standardu i koncentrowanie się na nim, przy czym w tym ujęciu standard ten może być dookreślany zarówno normami prawa UE, jak i prawa krajowego. W układzie stosunków nadzorczych na współczesnym rynku finansowym można jednak także wyróżnić konwergencję sieciowa. Wydaje się, że wprowadzenie pojęcia konwergencji sieciowej wiernie odzwier-

\footnotetext{
${ }^{5}$ Rozporządzenie Parlamentu Europejskiego i Rady nr 575/2013 z 26 czerwca 2013 r. w sprawie wymogów ostrożnościowych dla instytucji kredytowych i firm inwestycyjnych, zmieniające rozporządzenie (UE) nr 648/2012, Dz. Urz. UE L z 27 czerwca 2013 r., nr 176, s. 1 (dalej jako: rozporządzenie $\mathrm{CRR})$.
} 
ciedla zależności występujące na rynku finansowym w obszarze nadzoru, co wynika z „mozaikowatości” zespołów regulacji prawnych, które realizować maja cel stabilności finansowej. Powstajace normatywne wzorce nadzorcze, aby cechować się kompleksowościa, muszą uwzględniać regulacje powstające w sieci stabilności finansowej, w której np. w zakresie ogniwa gwarantowania depozytów dookreślany jest wzorzec konwergencyjny instytucji borykającej się z trudnościami finansowymi (dla której nie są wystarczające już mechanizmy nadzorcze, a rozważane być muszą albo mechanizmy restrukturyzacyjne, rekapitalizacyjne czy upadłościowe, a także regulacje dotyczące ochrony klienta-konsumenta na rynku usług finansowych). Wszystkie podmioty bezpieczeństwa finansowego tworzące sieć, zarówno na poziomie unijnym, jak i krajowym przyczyniają się do osiagnięcia stabilności finansowej, a funkcjonalne i strukturalne powiązania między poszczególnymi ogniwami tworzą fundament racjonalnego prowadzenia procesu konwergencyjnego na rynku finansowym, opartego na zasadzie proporcjonalności i ponoszenia odpowiedzialności za działania na rynku finansowym przez ten rynek, bez korzystania z pieniędzy budżetowych, a za to przy aktywnym udziale podmiotów tej sieci.

$\mathrm{Na}$ rynku finansowym UE dla prawidłowego zrekonstruowania normy prawnej nieodzowne jest czerpanie zarówno z postanowień ujednolicających rozporządzeń m.in. CRR, MIFIR ${ }^{6}$ oraz harmonizacyjnej dyrektywy CRD IV ${ }^{7}$, II dyrektywy MIFID czy Solvency II $^{8}$, jak i BTS-ów ${ }^{9}$ oraz ustawodawstwa krajowego, a także soft law ESA czy ERRS. Skoro konwergencja oznacza pewien normatywny, powstający w drodze nakazu prawa czy konsensu wzorzec normatywny, który we współczesnej architekturze finansowej musi uwzględniać sieciowo-płaszczyznowy charakter, to również ów wzorzec (np. prawidłowo działającej i prawidłowo nadzorowanej instytucji finansowej, wzorzec ochronny dla konsumenta rynku usług finansowych) uwzględniać musi elementy regulacyjne istotne dla poszczególnych ogniw sieci, a więc wzorce powinnego zachowania chylącej się ku upadkowi instytucji finansowej, instytucji podlegającej procesom restrukturyzacyjnym czy instytucji otrzymującej wsparcie płynnościowe. W tym natomiast kontekście uwidaczniać powinna się konwergencyjna rola podmiotów finansowych, zarządzających poszczególnymi ogniwami sieci stabilności finansowej ${ }^{10}$.

${ }^{6}$ Rozporządzenie Parlamentu Europejskiego i Rady (UE) nr 600/2014 z 15 maja 2014 r. w sprawie rynków instrumentów finansowych oraz zmieniające rozporządzenie (UE) nr 648/2010, Dz. Urz. UE L 173 z 12 czerwca 2014 r., s. 84.

7 Dyrektywa nr 2013/36/UE Parlamentu Europejskiego i Rady z 26 czerwca 2013 r. w sprawie warunków dopuszczenia instytucji kredytowych do działalności oraz nadzoru ostrożnościowego nad instytucjami kredytowymi i firmami inwestycyjnymi, zmieniająca dyrektywę 2002/87/WE, Dz. Urz. UE L z 27 czerwca 2013 r., nr 176, s. 338 (dalej jako: dyrektywa CRD IV).

8 Dyrektywa Parlamentu Europejskiego i Rady 2009/138/WE z 25 listopada 2009 r. w sprawie podejmowania i prowadzenia działalności ubezpieczeniowej i reasekuracyjnej (Wypłacalność II), Dz. Urz. UE L 335 z 17 grudnia 2009 r., s. 1 ze zm.

9 BTS (ang. binding technical standards), czyli wiążące standardy techniczne, które przyjmują formę rozporządzeń (wykonawczych lub delegowanych).

${ }_{10}$ Zob. m.in. J.H. Binder, Verbesserte Krisenprävention durch paneuropäische Aufsicht?: Zu neuen Aufsichtsinfrastruktur auf EU- Ebene, „Zeitschrift für Gemeinschaftsprivatrecht” 
Pojęcie konwergencji rozumianej na rynku finansowym jako zbliżanie przepisów prawnych dotyczących nadzoru finansowego ulega zatem dalszej specyfikacji w kierunku przyjęcia pojęcia konwergencji sieciowej jako procesu pełniej odzwierciedlającego zmiany architektury finansowej na rynku finansowym UE zarówno w wymiarze krajowo-unijnym, jak i w związku z powstaniem ESNF i EUB, istotnych dla rozważań nadzorczych w kontekście konwergencji treściowej i również instytucjonalnej, proceduralnej oraz w ujęciu sieciowym.

Chodzić bowiem może zarówno o konwergencję nadzorczą treściowo (rozumianą materialnoprawnie) - czyli zbliżanie przepisów prawnych oznaczać tutaj będzie koncentrowanie się na pewnych wyznaczonych przez prawodawcę UE normatywnych wzorcach nadzorczych, które mogą być określone w rozporządzeniu unijnym (a więc będą to wzorce jednolicie rozumiane i stosowane we wszystkich państwach członkowskich lub tylko harmonizowane, zatem wzorce te moga być dookreślane również na poziomie krajowym $\mathrm{z}$ uwagi na fakt ich regulacji w dyrektywie podlegającej implementacji w państwach członkowskich, co tworzy możliwość dookreślenia normatywnego kształtu tego wzorca) - jak i konwergencję proceduralną (formalnoprawna), wiązaną z tworzeniem wspólnych mechanizmów i procedur urzeczywistniania określonych interesów prawnych na rynku finansowym, jak również konwergencję nadzorczą instytucjonalną, która wiązana być musi z zalecaniem wdrażania do krajowych regulacji określonych sieciowych ram prawnych, jak dzieje się to w zakresie ram prawnych nadzoru makroostrożnościowego. Wszystkie wymienione typy konwergencji na rynku finansowym dotycza prawa nadzorczego na rynku finansowym UE z uwagi na zmianę paradygmatu regulacyjnego właśnie na nadzorczy. Dlatego zagadnienie konwergencji nadzorczej na rynku finansowym postrzegane jest przez pryzmat regulacji nadzorczych w wymienionych aspektach materialnoprawnym, proceduralnym i instytucjonalnym w ujęciu sieciowym. Analiza zjawiska konwergencji na rynku finansowym musi zatem uwzględniać sieciowy charakter podmiotów tworzących prawo rynku finansowego czy regulatorów nadzorczych, a także podmiotów, które w sposób szczególny predystynowane są do ochrony stabilności finansowej w ESSF ${ }^{11}$.

2011, nr 1, s. 34 i n. Warto w tym kontekście zaznaczyć, że „[...] Prawo wspólnotowe [obecnie unijne - M.F.], posługując się metodą harmonizacji, opiera się na różnorodności kulturowej państw członkowskich i wielości systemów prawnych, które stanowią podukłady wspólnotowego systemu prawnego" - M. Zirk-Sadowski, Wyktadnia i rozumienie prawa w Polsce po akcesji do Unii Europejskiej, w: S. Wronkowska (red.), Polska kultura prawna a proces integracji europejskiej, Kraków 2005, s. 113. W przypadku nadzoru na rynku finansowym UE oraz procesów konwergencji nadzorczej jest to już jednak w pewnych obszarach ujednolicenie materii regulacyjnej, które dokonuje się stopniowo. Pewne obszary prawa rynku finansowego stają się domena regulacyjną UE, będąc nadal materią dzielona, w istocie jednak podlegaja „uwspólnieniu” i staja się materią wyłączną UE.

${ }^{11}$ Szerzej zob. A. Jurkowska-Zeidler, Bezpieczeństwo..., passim; zob. też: T. Nieborak, Rynek finansowy jako dobro wspólne, „Ruch Prawniczy, Ekonomiczny i Socjologiczny” 79, 2017, z. 3, s. 161-174; A. Nadolska, Stabilność finansowa jako naczelna zasada prawa rynku finansowego, „Monitor Prawa Bankowego” 2015, nr 1, s. 84-95. 


\section{PRAWNE INSTRUMENTY I MECHANIZMY KONWERGENCJI NADZORCZEJ MIKROOSTROŻNOŚCIOWEJ}

W zakresie konwergencji materialnej (treściowej) warto zwrócić uwagę, że odbywa się ona obecnie głównie za pomocą rozporządzeń, w tym BTS-ów, czyli regulacyjnych i wykonawczych standardów technicznych. Jest to o tyle ciekawe, że przed kryzysem finansowym ciężar regulacyjny rynku finansowego spoczywał głównie na dyrektywach jako fundamentalnym narzędziu osiągania konwergencji nadzorczej. Po kryzysie finansowym konwergencja ta ma być już osiagana za pomocą aktów prawa, które wprowadzają ujednolicenie standardów normatywnych (np. w zakresie norm ostrożnościowych, które obecnie regulowane sa w rozporządzeniu $\mathrm{CRR}^{12}$ ) czy wywołuja potrzebę redefinicji zasad prawa bankowego (czy szerzej prawa rynku finansowego) ${ }^{13}$. Jest to konwergencja materialna, gdyż jej rezultatem na poziomie krajowym jest przyjęcie jednolicie rozumianych i stosowanych postanowień, przyjęcie jednolicie rozumianych i stosowanych wiążących wzorców nadzorczego postępowania, które adresowane są w postaci m.in. norm ostrożnościowych do instytucji finansowych, oraz norm z zakresu polityki ujawnień czy polityki wynagrodzeń. W ESNF zarówno na poziomie unijnym, jak i krajowym organy nadzorcze dbają o przestrzeganie norm nadzorczych, dookreślają sposób wykonywania obowiązków przez organy krajowe czy instytucje finansowe, również za pomoca nadzorczego soft law, BTS-ów, jak i zbierając oraz zarządzając informacjami mikro- i makroostrożnościowa, istotnymi w skali stabilności finansowej całego rynku UE. Warto w tym miejscu podkreślić znaczenie integracyjnej działalności Bazylejskiego Komitetu ds. Nadzoru Bankowego dla osiagania konwergencji nadzorczej na rynku finansowym, a zwłaszcza jego dokumentów Bazylea I, Bazylea II czy Bazylea III oraz „Podstawowych zasad efektywnego nadzoru bankowego", które stanowiąc przykłady funkcjonalnych źródeł prawa rynku finansowego UE, zostały wyrażone w wiążących aktach prawa $\mathrm{UE}^{14}$.

Uważać można, że konwergencja nadzorcza odbywa się zatem również w szerokim zakresie za pomoca nadzorczego soft law nowej generacji ${ }^{15} \mathrm{ESA}$. Jest to też konwergencja materialna (treściowa) wpływająca jednak na konwergencję instytucjonalna. Tytułem przykładu warto w tym miejscu wskazać m.in. na wytyczne EBA z 5 grudnia 2017 r. dotyczące procedur składania skarg w związku z możliwymi naruszeniami przepisów drugiej dyrektywy w sprawie usług płatniczych ${ }^{16}$, w których wskazuje się, jak należy stosować prawo euro-

${ }_{12}$ Szerzej M. Olszak, Regulacje systemu finansowego w Unii Europejskiej a Konstytucja Rzeczypospolitej Polskiej - wybrane zagadnienia, „Studia Europejskie” 2016, nr 4, s. 188 i n.

${ }^{13}$ Zob. A. Zalcewicz, Principles of banking law: comments in the light of amendments to the EU and national law, „Ius Novum” 2018, nr 2, s. 137-155.

${ }^{14}$ O Bazylejskim Komitecie ds. Nadzoru Bankowego zob. M. Olszak, Bankowe normy ostrożnościowe, Białystok 2011, s. 53, 91 i 103.

${ }^{15} \mathrm{O}$ soft law nowej generacji zob. M. Fedorowicz, Nadzór nad rynkiem finansowym Unii Europejskiej, Warszawa 2013, s. 150 i n.

${ }_{16}$ Zob. <https://www.eba.europa.eu/documents/10180/2053197/Guidelines+on+complaint+procedures+under+PSD2+\%28EBA-GL-2017-13\%29_PL.pdf/fb0e3136-5ada-402c-a42f-7cc359376457> 
pejskie w konkretnym obszarze. Zaznacza się jednak zarazem, że właściwe organy nadzorcze powinny stosować się do wytycznych przez wprowadzenie ich odpowiednio do swoich praktyk (np. przez dostosowanie swoich ram prawnych lub procesów nadzorczych ${ }^{17}$ ), również jeżeli wytyczne sa skierowane przede wszystkim do instytucji. Na podstawie art. 1 ust. 5 rozporządzenia o EBA (a także pozostałych rozporządzeń o ESA), EBA (ESA) przyczynia się do spójnego, efektywnego i skutecznego stosowania aktów prawa bankowego UE, a także wspiera konwergencję praktyk nadzorczych, przedstawia opinie Parlamentowi Europejskiemu, Radzie i Komisji oraz prowadzi analizy ekonomiczne rynków, dążąc do osiagnięcia wyznaczonego mu celu, którym jest urzeczywistnienie stabilności finansowej.

W sektorze bankowym rynku finansowego na podstawie art. 133 ust. 1a Prawa bankowego ${ }^{18}$ uwzględnianie zaleceń EBA należy do obowiązków $\mathrm{KNF}^{19}$. W ten sposób następuje też dookreślanie normatywnych wzorców zachowań instytucji finansowych, jak i konsumentów na rynku usług finansowych i niejednokrotnie właśnie ten sposób przeprowadzania konwergencji nadzorczej, jakkolwiek wywołujący kazuistyczność wzorców nadzorczych, wydaje się najczęściej stosowanym. W ramach analizowanego zagadnienia warto zauważyć, na kogo został nałożony obowiązek uwzględniania soft law i kształtowania się tych wzorców, gdyż udzielenie odpowiedzi na to pytanie pokazuje konwergencję nadzorczą od strony instytucjonalnej. Oczywiście do grona twórców soft law należy zaliczyć zarówno unijnych, jak i krajowych nadzorców, soft law i projekty BTS-ów powstają bowiem w dyskursie odbywającym się między unijnymi i krajowymi organami nadzoru. Z uwagi na sposób powstawania prawa na rynku finansowym UE oraz sieciowo-płaszczyznowy charakter nadzoru nad rynkiem finansowym, również konwergencja nadzorcza posiada charakter sieciowy. Instytucjonalnie bowiem, skoro każde z ogniw sieci stabilnościowej zaangażowane jest w osiaganie celu stabilności finansowej, można formułować twierdzenie o sieciowym ujęciu konwergencji nadzorczej w aspekcie instytucjonalno-funkcjonalnym.

$\mathrm{W}$ odniesieniu do konwergencji proceduralnej (formalnoprawnej), wiazanej z tworzeniem wspólnych mechanizmów i procedur urzeczywistniania określonych interesów prawnych na rynku finansowym UE, wskazać trzeba, że wyraża się ona m.in. przez udział krajowych organów nadzoru w tworzeniu soft law nadzorczego przez ESA oraz udział w tworzeniu projektów BTS-ów (w drodze otwartych lub publicznych konsultacji). W tym elemencie następuje zatem mocniejsze włączenie krajowych nadzorców w proces tworzenia prawa

[dostęp: 2.07.2018]. Wytyczne te mają zastosowanie do skarg składanych do właściwych organów w odniesieniu do możliwych naruszeń przez dostawców usług płatniczych przepisów dyrektywy (UE) 2015/2366.

${ }_{17}$ Wyróżnienie - M.F.

${ }_{18}$ Ustawa z 29 sierpnia 1997 r. - Prawo bankowe, t.jedn.: Dz. U. 2017, poz. 1876.

${ }_{19}$ Zob. szerzej D. Wojtczak-Samoraj, Soft law i mechanizmy nielegislacyjne jako instrumenty integracji rynku ustug bankowych Unii Europejskiej, „Monitor Prawa Bankowego” 2012, nr 1, s. 58 i n.; M. Fedorowicz, Nadzorcze soft law nowej generacji w sektorze bankowym w świetle art. 133 ust. 1 a ustawy Prawo bankowe, „Studia Prawnoustrojowe” 2017, nr 38, s. 29-44. 
nadzorczego rynku finansowego UE. Warto również zauważyć, że konwergencja proceduralna przejawia się w konstrukcji stosowania wiążącej decyzji nadzorczej przez ESA na podstawie art. 17, 18, 19 czy 9 ust. 5 rozporządzeń o ESA. W każdym z tych przypadków wiążąca decyzja unijnych nadzorców mikroostrożnościowych adresowana do krajowych nadzorców lub także, w szczególnych przypadkach, do instytucji finansowych może być zastosowana tylko wówczas, gdy nie działa lub wadliwie działać będzie nadzorca krajowy. Regulacja ta zakłada zatem konieczność kontaktowania się nadzorców krajowych z unijnymi i przeprowadzenia postępowania wyjaśniającego w ramach art. 17 rozporządzeń o ESA bądź postępowania mediacyjnego w ramach art. 19 rozporządzeń o ESA.

Z kolei konwergencja nadzorcza instytucjonalna wiązana być musi z zalecaniem wdrażania do krajowych regulacji określonych ram prawnych, w których organy i instytucje bezpieczeństwa finansowego realizują swoje cele i kompetencje w odniesieniu do nadzoru mikroostrożnościowego, co wyraża się w sieciowym i płaszczyznowym ujęciu nadzoru nad rynkiem finansowym w UE w postaci ESNF oraz utworzeniu na poziomie UE unijnych organów nadzoru mikroostrożnościowego odpowiedzialnych za poszczególne segmenty rynku finansowego UE: bankowy i usług płatniczych (EBA), kapitałowy (ESMA) oraz ubezpieczeniowy (EIOPA). To unijni nadzorcy mikroostrożnościowi wydają uwzględniane w prawodawstwie krajowym nadzorcze soft law unijne i są również prawodawcami faktycznymi BTS-ów i RTS-ów ${ }^{20}$. Najpełniej konwergencja instytucjonalna wyrażona została jednak w zaleceniu (ERRS) dotyczącym wdrożenia na poziomie krajowym ram prawnych nadzoru makroostrożnościowego.

Zauważyć należy, że konwergencja nadzorcza może się również dokonywać przez wykorzystanie instrumentów samoregulacji dostępnych dla instytucji finansowych. Zjawisko samoregulacji instytucji finansowych rozumiane może być jako możliwość precyzowania za pomoca polityk czy strategii sporządzanych przez banki wyznaczonych przez prawodawców czy regulatorów wzorców określonego postępowania ${ }^{21}$. Wskazane uszczegóławianie dokonywać się może np. w ramach instytucji kontroli wewnętrznej uregulowanej w art. 9-9f Prawa bankowego w ramach tworzonych polityk, procedur, planów czy analiz, które uwzględniać mogą wyższe standardy nadzorcze niż np. wyrażone w soft law EBA.

Z kolei powstanie EUB w filarze jednolitego mechanizmu nadzorczego pogłębia procesy konwergencji nadzorczej na tzw. szerokość i głębokość. W EUB konwergencję nadzorczą konkretyzować może sam EBC, na podstawie art. 6 ust. 3 (i odpowiednio art. 4 ust. 3 rozporządzenia 1024/201322) ma on bowiem kompetencję do wydawania wiążących instrukcji ${ }^{23}$ oraz wydawania rozporzą-

${ }^{20}$ RTS (ang. regulatory technical standards), czyli regulacyjne standardy techniczne.

${ }^{21}$ Zob. i por. D. Wojtczak-Samoraj, op. cit., s. 58 i n.

${ }^{22}$ Rozporządzenie Rady (UE) z 15 października 2013 r. powierzające Europejskiemu Bankowi Centralnemu szczególne zadania w odniesieniu do polityki związanej z nadzorem ostrożnościowym nad instytucjami kredytowymi, Dz. Urz. UE L 287 z 29 października 2013 r., s. 63.

${ }^{23} \mathrm{~W}$ EUB wiążący charakter wytycznych wynika z brzmienia art. 6 ust. 3 rozporządzenia 1024/2013, na mocy którego właściwe organy krajowe, jak określono w tym postanowieniu, „stosują się" do instrukcji EBC. 
dzeń mających na celu realizację i konkretyzację kompetencji nadzorczych. W EUB można argumentować o istnieniu specyficznej konwergencji, gdyż oprócz wymienionych instrumentów konwergencyjnych i mechanizmów konwergencji (w EUB ściśle ujednoliconych organizacyjnie i strukturalnie) istnieje możliwość prowadzenia konwergencji przez EBC, który ma kompetencję do stosowania krajowego prawa implementującego akty prawa UE, np. w zakresie regulacji rozporządzenia CRR i dyrektywy CRD IV na podstawie art. 4 ust. 3 rozporządzenia 1024/2013, zgodnie z którym dla celów wykonywania zadań powierzonych na mocy rozporządzenia 1024/2013 i dla zapewnienia wysokich standardów nadzoru EBC stosuje całe stosowne prawo unijne, a w przypadku gdy takie unijne prawo tworzą dyrektywy - również krajowe ustawy transponujące te dyrektywy. Z kolei gdy stosowne prawo unijne tworzą rozporządzenia oraz gdy obecnie rozporządzenia te wyraźnie dają państwom członkowskim opcje wyboru, EBC stosuje również ustawodawstwo krajowe dotyczące wykonywania tych opcji. W EUB EBC wydaje również wiążące instrukcje (art. 6 ust. 3 rozporządzenia 1024/2013) oraz wydaje tzw. rozporządzenia nadzorcze, czyli rozporządzenia wyłącznie w zakresie niezbędnym dla organizacji lub określenia zasad wykonywania zadań powierzonych mu na mocy rozporządzenia 1024/2013 (zgodnie z art. 4 ust. 3 tego rozporządzenia).

\section{PRAWNE INSTRUMENTY I MECHANIZMY KONWERGENCJI NADZORCZEJ MAKROOSTROŻNOŚCIOWEJ}

Powstaje pytanie, czy w odniesieniu do nadzoru makroostrożnościowego można mówić o istnieniu konwergencji nadzorczej, czy też specyfika tego nadzoru powoduje powstanie innych jeszcze wzorców konwergencyjnych. Należy pokrótce przypomnieć, że nadzór makroostrożnościowy jest złożona, wielopłaszczyznowa, hybrydowa struktura nadzorcza, znajdująca swoje zakorzenienie w ESSF. Specyfika nadzoru makroostrożnościowego jako unijno-krajowej instytucji nadzorczej polega na tym, że jeśli na poziome UE identyfikowane sa ryzyka systemowe w UE i rozwijana jest działalności prewencyjna (ex ante), to na poziomie krajowym oprócz, również realizowanej działalności prewencyjnej, podejmowane są także czynności operacyjne, czynności związane z zarządzaniem kryzysowym w razie powstałego już ryzyka systemowego (działalność ex post). Złożony, hybrydowy charakter tej struktury polega natomiast na tym, że materialnie zakres przedmiotowy nadzoru makroostrożnościowego jest określony bardzo szeroko, jako wszystko to, co w systemie finansowym może rodzić ryzyko systemowe zakłócające funkcjonowanie gospodarki. W zakresie przedmiotowym nadzoru makroostrożnościowego znajduje się również przestrzeganie przepisów buforowych, które zostały uregulowane w rozporządzeniu CRR i dyrektywie CRD IV i implementowane do prawodawstw krajowych.

Można twierdzić, że z uwagi na specyfikę i budowę nadzoru makroostrożnościowego konwergencja nadzorcza $\mathrm{w}$ tym aspekcie przebiega odmiennie od konwergencji nadzorczej w odniesieniu do nadzoru mikroostrożnościowego, 
gdyż w większym stopniu odnosi się do konwergencji instytucjonalnej. Podstawowym instrumentem procesów konwergencyjnych dla nadzoru makroostrożnościowego jest właściwy i szybki przepływ informacji makroostrożnościowo istotnej pomiędzy wszystkimi podmiotami sieci stabilnościowej, w tym zwłaszcza pomiędzy makroostrożnościowym nadzorem krajowym a unijnym. Informacja makroostrożnościowo istotna i właściwe nią zarządzanie jest tutaj instrumentem procesu konwergencyjnego, ex ante oddziałującego na system finansowy UE.

To, co jest charakterystyczne dla nadzoru makroostrożnościowego, to w znacznej mierze niewiążący charakter jego norm, przyjęcie bowiem określonych ram prawnych nadzoru makroostrożnościowego wyrażonych w zaleceniu ERRS/2011/3 w sprawie mandatu makroostrożnościowego ${ }^{24}$ nie było wiążące prawnie, a mimo to państwa członkowskie wprowadziły je do swoich ustawodawstw wewnętrznych. Oczywiście wdrożenie postanowień (materialnych) o buforach kapitałowych oraz dotyczących utrzymania tych buforów na określonym poziomie jest wiażące dla państw członkowskich, gdyż uregulowane zostało w dyrektywie CRD IV i rozporządzeniu CRR. Ani jednak unijny nadzorca makroostrożnościowy, ani - w Polsce - Komitet Stabilności Finansowej jako organ makroostrożnościowy, nie mają wiążących kompetencji w zakresie spraw nadzoru makroostrożnościowego czy zarządzania kryzysowego, w tym więc organizacyjno-instytucjonalnym wymiarze nadzór makroostrożnościowy jest nadzorem tzw. miękkim, a jego znaczenie wyraża się właśnie w sieciowym ujęciu i funkcjonalnym połączeniu zadań oraz kompetencji poszczególnych „stabilnościowych” gremiów decyzyjno-regulacyjnych na „szczeblu” UE i krajowym. Tylko w zakresie polityki buforowej można obserwować posługiwanie się przez prawodawcę UE i ustawodawców krajowych wiążącymi normami prawnymi uregulowanymi w rozporządzeniu CRR, dyrektywie CRD IV oraz w krajowych wiążących aktach prawnych. W tym elemencie również nadzór makroostrożnościowy jest nadzorem sieciowym i wielopłaszczyznowym, a więc $\mathrm{i}$ tu konwergencja nadzorcza jest rozpatrywana sieciowo. W tym przypadku jednak konwergencja zapewniana jest $\mathrm{w}$ większym stopniu instytucjonalnie, stworzenie bowiem - dzięki zaleceniu ERRS - krajowych ram prawnych nadzoru makroostrożnościowego pomogło od strony instytucjonalnej w sieciowym zakorzenieniu nadzoru makroostrożnościowego. Natomiast pole normatywne nadzoru makroostrożnościowego, oprócz wiążących postanowień buforowych, pozostawiono do regulacji na poziomie krajowym. W elemencie zatem dotyczącym przeciwdziałania ryzyku systemowemu pozostawiono organom krajowym swobodę decyzyjną zarówno co do struktury instytucjonalnej tego nadzoru, jak i instrumentów, którymi nadzór ten ma się posługiwać, pokazując jedynie wzorzec struktury instytucjonalnej ERRS, który w znacznym stopniu został m.in. przejęty w polskiej regulacji nadzoru makroostrożnościowego ${ }^{25}$. W od-

${ }^{24}$ Zalecenie ERRS z 22 grudnia 2011 r. w sprawie mandatu makroostrożnościowego organów krajowych, Dz. Urz. UE C 41 z 14 lutego 2012 r., s. 1.

${ }^{25}$ Ustawa z 5 sierpnia 2015 r. o nadzorze makroostrożnościowym nad systemem finansowym i zarządzaniu kryzysowym w systemie finansowym, t.jedn.: Dz. U. 2017, poz. 1934. 
niesieniu do przepisów buforowych, czyli jednego z elementów nadzoru makroostrożnościowego, można wskazać, że konwergencja nadzorcza przebiega tutaj przez stworzenie i wdrażanie w państwach członkowskich nowych instytucji prawnych (w sensie przedmiotowym), czyli buforów: zabezpieczajacego, antycyklicznego, ryzyka systemowego, czy bufora instytucji o znaczeniu systemowym, w których oczywiście przejawia się konwergencja treściowa.

W odniesieniu do trzeciej z wyszczególnionych metod osiagania konwergencji nadzorczej, samoregulacji instytucji finansowych, w odniesieniu do nadzoru makroostrożnościowego procesy te nie występuja, co wynika i jest związane $\mathrm{z}$ istotą tego nadzoru, jako nadzoru systemowego, który nie jest regulowany z punktu widzenia pojedynczej instytucji finansowej. Choć można też zauważyć, że w $§ 21$ rozporządzenia Ministra Finansów z 2017 r. przewidziano mechanizm, w ramach którego istnieje możliwość oceny ex ante produktów i usług finansowych z punktu widzenia spełniania przez te produkty wymogów dopuszczalnego ryzyka w działalności bankowej, zgodnie ze strategia zarządzania ryzykiem ${ }^{26}$, a więc można uważać, że także potencjalnie istnienie $\mathrm{w}$ danym produkcie ryzyka natury systemowej, powiązanego z wadliwą konstrukcją danego produktu, może nieść zagrożenia systemowe ${ }^{27}$.

W odniesieniu do konwergencji proceduralnej (formalnoprawnej), wiązanej z tworzeniem wspólnych mechanizmów i procedur urzeczywistniania określonych interesów prawnych na rynku finansowym w nadzorze makroostrożnościowym wskazać trzeba na mechanizmy unormowane w art. 458 rozporządzenia CRR, dzięki którym następować może szerokie włączenie krajowych organów nadzoru makroostrożnościowego w likwidowanie ryzyka systemowego czy makroostrożnościowego we współpracy z ERRS, KE, EBA i Rada.

Powyższe analizy nakazuja przyjęcie stanowiska, że konwergencja nadzorcza instytucjonalna najbardziej eksponowana jest $\mathrm{w}$ regulacji nadzoru makroostrożnościowego. To państwa członkowskie UE, wdrażając zalecenie ERRS/2011/3 w sprawie mandatu makroostrożnościowego, w większości przypadków mocno wzorowały się na regulacji ERRS jako normatywnym wzorcu krajowych organów nadzoru makroostrożnościowego ${ }^{28}$. Sieciowość nadzoru makroostrożnościowego wyraża się właśnie w zbudowaniu nie tylko unijnych, ale również krajowych - operacyjnych ram prawnych nadzoru makroostrożnościowego i zarządzania kryzysowego, przez co dopełnia się sieć europejskiej stabilności finansowej o nowy rodzaj nadzoru - makroostrożnościowego. Nadzór makroostrożnościowy, obok mikroostrożnościowego, współtworzy pokryzy-

${ }^{26}$ Rozporządzenie Ministra Rozwoju i Finansów z 6 marca 2017 r. w sprawie systemu zarządzania ryzykiem i systemu kontroli wewnętrznej, polityki wynagrodzeń oraz szczegółowego sposobu szacowania kapitału wewnętrznego w bankach, Dz. U. 2017, poz. 637.

${ }^{27}$ M. Fedorowicz, System zarzadzania ryzykiem i system kontroli wewnętrznej w bankach, Komentarz praktyczny Lex dla Banków nr 320628.

${ }_{28}$ Zob. na temat instytucjonalnych ram prawnych nadzoru makroostrożnościowego w państwach członkowskich UE: A. Dobrzańska, Polityka makroostrożnościowa - zagadnienia instytucjonalne. Teoria i dotychczasowe doświadczenia w Unii Europejskiej, Materiały i Studia NBP nr 307, Warszawa 2014, passim; eadem, Kolegialne organy makroostrożnościowe $w$ UE - analiza rozwiqzań instytucjonalnych, „Bezpieczny Bank” 2018, nr 1, s. 52-68. 
sową konstrukcję ESNF, wzajemnie się dopełniających filarów nadzoru mikroi makroostrożnościowego, wyznaczających normatywne wzorce dla krajowych nadzorców mikro- i makroostrożnościowych oraz stanowiących - obok działalności stabilnościowej i nadzorczej EBC czy ogniwa gwarantowania depozytów - o współczesnej architekturze sieci stabilności finansowej.

\section{UWAGI KOŃCOWE}

Konwergencja nadzorcza jest przedmiotem szerszego zagadnienia: integracji nadzorczej odbywajacacej się na rynku finansowym UE po kryzysie finansowym. Powiązania systemów prawa krajowego i unijnego są tak intensywne, że dla rekonstrukcji normy prawnofinansowej mającej zastosowanie w konkretnej sytuacji potrzebna jest rekonstrukcja normy traktatowej, normy z rozporządzenia unijnego, normy krajowej i soft law finansowego. Konwergencja odbywa się zatem na wszystkich poziomach i w ramach różnych form działalności regulacyjnej (nadzorców unijnych i krajowych), a także prawodawców (unijnych i ustawodawcy krajowego). Można zauważyć, że tak jak analiza współczesnej architektury finansowej na rynku finansowym UE najpełniejsza jest w ujęciu sieciowym, tak również analiza tworzenia prawa na rynku finansowym, jak i analiza zjawiska konwergencji nadzorczej, jej poziomów, celów i kryteriów najpełniejsza będzie właśnie w układzie sieciowym. Najprostszym tłumaczeniem dla zasadności takiej sieciowej i wielopłaszczyznowej analizy zależności oraz powiązań na rynku finansowym UE byłoby sumaryczne zestawienie celów i kompetencji wszystkich podmiotów bioracych udział $\mathrm{w}$ procesie powstawania i stosowania prawa nadzorczego na rynku finansowym UE, czy szerzej - prawa finansowego w ogóle. Byłoby to jednak zbyt mocne uproszczenie. Dla wnikliwej analizy istotna jest raczej koncentracja na fundamentalnym celu prawodawców i regulatorów - stabilności finansowej. Pojęcie to już otrzymało i nadal otrzymuje wymierna normatywną treśćc ${ }^{29}$, która może, a wręcz musi służyć normatywnemu wyrażeniu normy prawnej ${ }^{30}$.

Tak jak przybliżono w artykule, podstawa prawidłowej konwergencji nadzorczej zarówno od strony regulacyjnej, jak i wykonawczej (czyli stosowania norm nadzorczych) jest istnienie, a następnie właściwe zarządzanie informacją nadzorcza, która również jest informacją sieciowa, gdyż jej przepływ musi być zapewniony między wszystkimi ogniwami sieci stabilności finansowej. Dokonując oceny procesu sieciowej konwergencji nadzorczej na rynku finan-

29 A. Jurkowska-Zeidler, Bezpieczeństwo..., passim; M. Fedorowicz, O normatywnym pojęciu stabilności finansowej na rynku finansowym Unii Europejskiej w nowej architekturze nadzorczej, „Studia Europejskie” 2017, nr 4, s. 73-94.

30 A. Zalcewicz, referat: Stabilność krajowego systemu finansowego jako określenie stużace wyrażeniu normy prawnej (referat udostępniony za zgodą Autorki), Ogólnopolska Konferencja Naukowa „Rola bankowości centralnej w zapewnieniu stabilności finansowej rynku finansowego”, Wrocław, 17 maja 2013 r. 
sowym UE, należy zauważyć, że oprócz oczywistych zalet związanych z ujednoliceniem pojęć istotnych dla rynku finansowego oraz jednolitego rozumienia w obszarze normatywnym UE norm ostrożnościowych, pojawiają się również problemy wiązane z ograniczeniem opcyjności i swobody decyzyjnej krajowych organów nadzoru na rynku finansowym. Unormatywnienie pojęć, formułowanie definicji legalnych powodujących związanie organów nadzorczych $\mathrm{w}$ procesie stosowania prawa uniemożliwia uwzględnienie specyfiki nadzoru rynkowego na rynkach lokalnych państw członkowskich UE. Również w zakresie tworzenia soft law nadzorczego na rynku finansowym UE proces ten ze względu na obowiązki konsultacyjne na poziomie krajowym jest wydłużony. Procedura ta wymaga uwzględnienia jednak zasady proporcjonalności i respektowania stanowiska krajowych organów nadzoru. Warto przypomnieć, że znaczący wpływ na konwergencję nadzorczą na rynku finansowym UE ma Bazylejski Komitet ds. Nadzoru Bankowego. Jego działalność od lat przyczynia się do wzmocnienia konwergencji nadzorczej, mimo że wytwory działalności Komitetu nie mają charakteru wiążącego prawnie, to jednak są uwzględniane w dyrektywach unijnych i wdrażane do krajowych ustawodawstw państw członkowskich.

Skoro w niniejszym opracowaniu sposoby osiagania konwergencji nadzorczej podzielono na instrumenty i mechanizmy, to należy wskazać, że do instrumentów konwergencji nadzorczej należy zaliczyć instrumenty konwergencji wiążącej i niewiążącej ${ }^{31}$. Do instrumentów konwergencji wiążącej zakwalifikować trzeba, po pierwsze, instrument rozporządzenia, w tym BTS-ów i RTS-ów, dzięki którym osiagana jest na rynku finansowym konwergencja materialna, i to w stopniu maksymalnym (skoro rozporządzenia, w tym również delegowane i wykonawcze, są bezpośrednio skuteczne i stosowalne oraz jednolicie rozumiane i stosowane przez wszystkie podmioty w państwach członkowskich); po drugie, instrument decyzji (o jak na razie nikłej przydatności praktycznej) wydawanej przez unijnych nadzorców mikroostrożnościowych na podstawie art. 17,18 i 19 czy art. 9 ust. 5 rozporządzeń o ESA, dzięki jej wiążącemu charakterowi prawnemu i skutkowi pierwszeństwa stosowania; po trzecie, niewiążącym instrumentem konwergencji nadzorczej jest unijne, nadzorcze soft law, które często podlega utwardzeniu przy kolejnych zmianach prawa (w BTS-ach, dyrektywach czy rozporządzeniach) lub też podlega włączeniu do krajowych regulacji rynku finansowego.

Z kolei wśród mechanizmów konwergencji nadzorczej na pierwszym planie plasują się sieciowe mechanizmy osiągania konwergencji nadzorczej. Skoro nadzór zarówno mikro-, jak i makroostrożnościowy mają charakter wielopłaszczyznowy, sieciowy (stanowią bowiem elementy ESSF), to również konwergencja nadzorcza na rynku finansowym jest normatywnie zakotwiczona

31 Przez pojęcie konwergencji wiążącej rozumieć można sytuacje, w których na podstawie normy prawnej bezpośrednio wiążącej i stosowalnej lub wiążącej decyzji nadzorczej następuje związanie adresatów tych norm. Z kolei w przypadku „konwergencji niewiążącej” adresaci norm, jakkolwiek formalnie nie są związani wzorcami powinnego zachowania, to jednak z uwagi na potrzebę integracji rynku finansowego UE i zapewnienia funkcjonalnej zbieżności na tym rynku wdrażają i stosują te wzorce w krajowych ustawodawstwach. 
w sieciowym mechanizmie regulacyjnym, dla którego normatywnym mianownikiem i celem legislacyjnym jest normatywizujace się coraz bardziej pojęcie stabilności finansowej ${ }^{32}$.

Podstawową konkluzją niniejszego artykułu jest konieczność wyodrębnienia pojęcia „konwergencja sieciowa” na rynku finansowym UE. W każdym z wyszczególnionych i analizowanych aspektów konwergencji: materialnej (treściowej), proceduralnej i instytucjonalnej pojawiają elementy normatywne wiąane z sieciowym układem architektury finansowej na rynku finansowym UE. Zbliżanie nadzorczych przepisów prawnych na rynku finansowym UE wiąże się przede wszystkim z ideą ESSF i wzajemnymi, funkcjonalnymi powiązaniami między poszczególnymi ogniwami tej sieci, budowanymi zarówno na poziomie UE, jak i na poziomie krajowym. Konwergencja sieciowa dobrze odzwierciedla, że w sytuacji, w której działania nadzorcze już nie wystarczą (ani mikro-, ani makroostrożnościowe), pojawia się konieczność określenia wzorców powinnego zachowania się instytucji finansowej chylącej się ku upadłości (w procesie restrukturyzacji odbywającej się w zgodzie z klauzula bail-in) czy instytucji upadającej (gwarantującej wypłatę depozytów swoim klientom), czy działalności banku centralnego jako pożyczkodawcy ostatniej instancji. Konwergencja sieciowa w tym ujęciu oznacza konieczność nie tylko właściwego uporządkowania powiązań między poziomem krajowym a unijnym, ale również pomiędzy poszczególnymi ogniwami, podmiotami sieci stabilności finansowej. Dla prawodawcy UE jest to cel tak fundamentalny, że zgodnie z art. 29 rozporządzeń o ESA organy te mają być aktywne w tworzeniu wspólnej unijnej kultury nadzoru i spójnych praktyk nadzorczych, a także w zapewnianiu jednolitych procedur i spójnych podejść na terytorium Unii, a w tym celu mogą tworzyć nowe, praktyczne instrumenty i narzędzia służące zwiększaniu konwergencji.

Konwergencja nadzorcza na rynku finansowym, która charakteryzuje się włączeniem w procesy decyzyjne i tworzenia struktur nadzorczych krajowych nadzorców i inne podmioty sieci stabilności finansowej, jest jednak procesem czasochłonnym i pracochłonnym, wydłużającym czas podejmowania decyzji na rynku finansowym oraz ograniczającym swobodę decyzyjną krajowych nadzorców, jak i potęgującym zjawisko inflacji prawa na rynku finansowym. Jest jednak, jak można wskazać, kosztem, który należy ponieść dla zapewnienia stabilności finansowej i jednolitości rozumienia nadzoru oraz poszanowania zasady proporcjonalności i demokratycznej legitymizacji decyzji podejmowanych na współczesnym rynku finansowym UE.

dr hab. Magdalena Fedorowicz

Profesor Uniwersytetu im. Adama Mickiewicza w Poznaniu magfed@amu.edu.pl

https://orcid.org/0000-0002-5578-5170

${ }^{32}$ M. Fedorowicz, O normatywnym ..., s. 73-94. 


\section{LEGAL INSTRUMENTS AND MECHANISMS FOR ACHIEVING SUPERVISORY MICRO- AND MACROPRUDENTIAL CONVERGENCE IN EU FINANCIAL MARKET}

\section{Summary}

The aim of this paper is to identify and analyse the net convergence on the financial market due to supervisory convergence on the financial market in the microprudential and macroprudential systemic approach and to place this process in the financial net reliance after the legal changes implemented by the European System of Financial Supervision and European Banking Union. In particular, instruments and mechanisms of the EU and national (Polish) instruments and mechanisms for achieving supervisory convergence were analysed, which is a sine qua non for achieving the objective of financial stability, illustrating at the same time the convergence of financial administration in the EU financial market and the legal effects and results of this convergence in institutional, procedural, substantive and network dimensions. The thesis of the study is that three equivalent, necessary and complementary regulatory ways of achieving supervisory convergence in the financial market can be identified. 
